\title{
Regulation of TRP-like muscarinic cation current in gastrointestinal smooth muscle with special reference to $\mathrm{PLC} / \mathrm{InsP}_{3} / \mathrm{Ca}^{2+}$ system
}

\author{
Alexander V ZHOLOS ${ }^{1}$ \\ Department of Physiology, Queen's University Belfast, Belfast, UK
}

\section{Key words}

smooth muscle; muscarinic receptor; $\mathrm{G}$ protein; phospholipase $\mathrm{C}$; $\mathrm{InsP}_{3}$; calcium; TRP cation channel

\author{
${ }^{1}$ Correspondence to Prof A V ZHOLOS. \\ Phn 44-28-9097-2705. \\ Fax 44-28-9097-5775. \\ E-mail a.zholos@qub.ac.uk
}

Received 2006-05-19

Accepted 2006-05-30

doi: $10.1111 /$ j.1745-7254.2006.00392.x

\begin{abstract}
Acetylcholine, the main enteric excitatory neuromuscular transmitter, evokes membrane depolarization and contraction of gastrointestinal smooth muscle cells by activating $\mathrm{G}$ protein-coupled muscarinic receptors. Although the cholinergic excitation is generally underlined by the multiplicity of ion channel effects, the primary event appears to be the opening of cation-selective channels; among them the $60 \mathrm{pS}$ channel has been recently identified as the main target for the acetylcholine action in gastrointestinal myocytes. The evoked cation current, termed $\mathrm{m} \mathrm{I}_{\mathrm{CAT}}$, causes either an oscillatory or a more sustained membrane depolarization response, which in turn leads to increases of the open probability of voltage-gated $\mathrm{Ca}^{2+}$ channels, thus providing $\mathrm{Ca}^{2+}$ entry in parallel with $\mathrm{Ca}^{2+}$ release for intracellular $\mathrm{Ca}^{2+}$ concentration rise and contraction. In recent years there have been several significant developments in our understanding of the signaling processes underlying $\mathrm{mI}_{\mathrm{CAT}}$ generation. They have revealed important synergistic interactions between $\mathrm{M}_{2}$ and $\mathrm{M}_{3}$ receptor subtypes, single channel mechanisms, and the involvement of TRPC-encoded proteins as essential components of native muscarinic cation channels. This review summarizes these recent findings and in particular discusses the roles of the phospholipase $\mathrm{C} / \mathrm{InsP}_{3} /$ intracellular $\mathrm{Ca}^{2+}$ release system in the $\mathrm{mI} I_{\text {CAT }}$ physiological regulation.
\end{abstract}

\section{Introduction}

It has long been known that in visceral smooth muscle cells acetylcholine (ACh) acts as an excitatory neurotransmitter $^{[1]}$. Thus, as the primary excitatory transmitter released by enteric motor neurons, ACh plays a central role in the control of complex patterns of motility of the gastrointestinal (GI) tract ${ }^{[2]}$. The excitatory input is received by $\mathrm{G}$ proteincoupled muscarinic ACh receptors ( $\mathrm{mAChR}$ ) expressed in postjunctional cells-smooth muscle myocytes with the involvement of interstitial cells of Cajal ${ }^{[3-5]}$. ACh binding to $\mathrm{mAChRs}$ triggers a complex array of membrane and intracellular signals leading to membrane depolarization and smooth muscle contraction, respectively ${ }^{[5,6]}$.

GI muscles in various species and various regions of the digestive tract express predominantly, if not exclusively, the $\mathrm{M}_{2}$ and $\mathrm{M}_{3}$ subtypes of $\mathrm{mAChRs}$ which are present typically at a ratio between $5: 1$ and 4:1 $1^{[3,7-9]}$. The cholinergic contractile response is usually accompanied by membrane depolarization and/or the occurrence of slow waves and accelerated action potential discharge with a concomitant increase of the membrane conductance ${ }^{[10-16]}$. The excitatory effect of mAChR stimulation is mainly attributed to the activation of cation $\left(\mathrm{Na}^{+}\right.$and $\left.\mathrm{Ca}^{2+}\right)$ or chloride conductances, or sometimes to the inhibition of potassium conductance, with the secondary activation of voltage-dependent $\mathrm{Ca}^{2+}$ channels (VDCC). Therefore, the excitatory action of ACh can be seen as an integral and important mechanism of the contractile response because it initiates $\mathrm{Ca}^{2+}$ influx through VDCCs. This $\mathrm{Ca}^{2+}$ entry signal can summate with the well-documented $\mathrm{ACh}$-induced intracellular $\mathrm{Ca}^{2+}$ release, and these additive $\mathrm{Ca}^{2+}$ sources are necessary to maintain smooth muscle contraction.

Indeed, pharmacological blockade of L-type $\mathrm{Ca}^{2+}$ channels does not prevent membrane depolarization in response to $\mathrm{mAChR}$ stimulation ${ }^{[17]}$ but strongly reduces the contrac- 
tile response ${ }^{[18-21]}$, indicating that this voltage-dependent $\mathrm{Ca}^{2+}$ entry is important for the cholinergic contraction rather than membrane depolarization.

The cholinergic GI smooth muscle contraction is generally regarded as an $\mathrm{M}_{3}$ response mediated by the main universal $\mathrm{Ca}^{2+}$ signalling pathway $\mathrm{G}_{\mathrm{q} / 11}$ coupled to phospholipase C- $\beta$ (PLC- $\beta$ ) activation, which in turn hydrolyzes phosphatidylinositol 4,5-bisphosphate ( $\left.\mathrm{PIP}_{2}\right)$ into 1,2-diacylsn-glycerol (DAG) and D-myo-inositol 1,4,5-trisphosphate $\left(\operatorname{Ins} \mathrm{P}_{3}\right)^{[22]}$. By rapidly releasing $\mathrm{Ca}^{2+}$ from the sarcoplasmic reticulum $\mathrm{InsP}_{3}$ evokes a transient intracellular $\mathrm{Ca}^{2+}$ concentration $\left(\left[\mathrm{Ca}^{2+}\right]_{\mathrm{i}}\right)$ increase, thus initiating the myocyte contraction. Conversely, the major $\mathrm{M}_{2}$ subtype apparently plays a central and direct role in many ion channel effects but its role in the cholinergic contraction is less clear. Unno et $a l^{[21]}$ recently addressed the specific roles of $\mathrm{M}_{2}$ and $\mathrm{M}_{3}$ receptors in agonist-evoked contraction of the guinea pig ileal longitudinal smooth muscle. Their results suggest that cholinergic contractions primarily originate from the integration of $\mathrm{Ca}^{2+}$ entry and $\mathrm{Ca}^{2+}$ sensitization of myofilaments. The authors thus conclude that $\mathrm{M}_{3}$-mediated $\mathrm{Ca}^{2+}$ store release might contribute to the contraction indirectly through potentiation of the electrical membrane responses.

Central to this hypothesis is the notion that muscarinic cation channel activation is strongly potentiated by $\left[\mathrm{Ca}^{2+}\right]_{\mathrm{i}}^{[23,24]}$. Although $\mathrm{m} I_{\mathrm{CAT}}$ in smooth muscle cells has been extensively characterized as an $\mathrm{M}_{2}$-mediated pertussis toxin-sensitive response primarily resulting from $\mathrm{G}_{\mathrm{o}}$ activation ${ }^{[25-30]}$, accumulating evidence suggests that $\mathrm{mI}_{\mathrm{CAT}}$ is in fact a mixed $\mathrm{M}_{2} /$ $\mathrm{M}_{3}$ response ${ }^{[31-35]}$. Therefore, the hypothesis that an interaction between $\mathrm{M}_{2}$ and $\mathrm{M}_{3}$ receptors plays a crucial role in the contractile response ${ }^{[21]}$ is consistent with the synergistic activation of the muscarinic cation channels by both mAChR subtypes. This review discusses $m I_{\text {CAT }}$ regulation with the involvement of various $\mathrm{M}_{2^{-}}, \mathrm{M}_{3^{-}}$, and $\mathrm{Ca}^{2+}$-dependent signaling pathways.

\section{Muscarinic effects on ion channels in GI smooth muscles}

It has long been known that the depolarizing effect of ACh and other muscarinic agonists on GI smooth muscles is mediated mostly by an increase in the $\mathrm{Na}^{+}$permeability ${ }^{[12]}$. However, the reversal potential of carbachol-evoked currents in the intestinal smooth muscle is approximately -10 $\mathrm{mV}$ and sensitive to changes in both $\left[\mathrm{Na}^{+}\right]_{\mathrm{o}}$ and $\left[\mathrm{K}^{+}\right]_{\mathrm{o}}$, but relatively insensitive to changes in $\left[\mathrm{Cl}^{-}\right]_{0}^{[15]}$, which indicates a non-selective increase in membrane permeability.

More recently, multiple muscarinic ion channel effects have been described in voltage-clamped cells, which include generation of inward cationic or chloride current, inhibition or potentiation of voltage-dependent $\mathrm{Ca}^{2+}$ current, and modulation of several types of $\mathrm{K}^{+}$currents (reviewed in detail elsewhere $\left.^{[3,5,6,36,37]}\right)$.

Consistent with the direct role of the $\mathrm{M}_{2}$ receptor, some ion channel effects of muscarinic agonists are reduced or even abolished by pertussis toxin treatment (eg, cation channel activation, $\mathrm{BK}_{\mathrm{Ca}}$ channel inhibition), which selectively uncouples $\mathrm{M}_{2}$ receptors from $\mathrm{G}_{\mathrm{i}} / \mathrm{G}_{\mathrm{o}}$ proteins. Conversely, $\mathrm{M}_{3}$ receptors typically modulate ion channels indirectly through $\mathrm{G}_{\mathrm{q} / 11}$ coupling to PLC- $\beta$ activation and accumulation of InsP $\mathrm{P}_{3}$ and DAG. InsP $\mathrm{P}_{3}$ evokes a transient $\left[\mathrm{Ca}^{2+}\right]_{\mathrm{i}}$ increase by $\mathrm{Ca}^{2+}$ release, whereas DAG initiates the translocation and activation of protein kinase $\mathrm{C}(\mathrm{PKC})$ in a $\mathrm{Ca}^{2+}$-dependent manner. These second messenger pathways are often interposed between $\mathrm{M}_{3}$ receptors and target channels, notably those sensitive to $\left[\mathrm{Ca}^{2+}\right]_{\mathrm{i}}$ (ie, potentiation of cationic, $\mathrm{Cl}^{-}$and $\mathrm{BK}_{\mathrm{Ca}}$ channels and inhibition of VDCC).

From these studies, clear implications arise concerning the functional importance of the numerous muscarinic effects on ion channels. Opening of cationic and $\mathrm{Cl}^{-}$channels will produce membrane depolarization, thus promoting $\mathrm{Ca}^{2+}$ influx for the contractile response. As both types of channels are $\left[\mathrm{Ca}^{2+}\right]_{\mathrm{i}}$-sensitive they were proposed to be involved in a positive feedback loop whereby $\mathrm{Ca}^{2+}$ entry and $\mathrm{Ca}^{2+}$ release promote membrane depolarization and further $\mathrm{Ca}^{2+}$ influx ${ }^{[38,39]}$, termed $\mathrm{Ca}^{2+}$-induced $\mathrm{Ca}^{2+}$ entry ${ }^{[40]}$. This action might be further facilitated by the muscarinic inhibition of several types of $\mathrm{K}^{+}$channels, such as $\mathrm{BK}_{\mathrm{Ca}}$, delayed rectifier and $\mathrm{K}_{\text {ATP }}$ channels ${ }^{[37]}$. There are also mechanisms that provide negative feedback control by either limiting (VDCC channel inhibition, $\mathrm{mI}_{\mathrm{CAT}}$ desensitization) or terminating $\left(\mathrm{BK}_{\mathrm{Ca}}\right.$ activation) cholinergic membrane depolarization.

\section{General properties of $\mathrm{mAChR}$-operated cation channels}

Muscarinic effects on many different channels, which occur in parallel, raise the challenging task of understanding their relative importance, especially in the context of the interactions between $\mathrm{M}_{2}$ and $\mathrm{M}_{3}$ receptors. However, activation of $\mathrm{mI}_{\mathrm{CAT}}$ is undoubtedly one of the major mechanisms of GI smooth muscle excitation. Cation channels carrying $\mathrm{m} I_{\mathrm{CAT}}$ in many smooth muscles have relatively low $\mathrm{Ca}^{2+}$ permeability ${ }^{[23,41,42]}$ (eg, with $110 \mathrm{mmol} / \mathrm{L}$ extracellular $\mathrm{CaCl}_{2}$ and 145 $\mathrm{mmol} / \mathrm{L}$ intracellular $\mathrm{CsCl}$, a $\mathrm{P}_{\mathrm{Ca}} / \mathrm{P}_{\mathrm{Cs}}$ ratio of 2.8 was estimated ${ }^{[43]}$ ); therefore the major pathway for $\mathrm{Ca}^{2+}$ entry is through VDCC. However, in some smooth muscles, $\mathrm{Ca}^{2+}$ permeability of this channel is more substantial providing an additional $\mathrm{Ca}^{2+}$ influx ${ }^{[44}$ 46]. For example, in tracheal myocytes 
the fraction of the cationic current carried by $\mathrm{Ca}^{2+}$ at $-60 \mathrm{mV}$ under physiological ion gradients was estimated at $14 \%{ }^{[45]}$, but in guinea pig gastric myocytes it amounts to only $1 \%{ }^{[43]}$. The relative channel permeability to various monovalent cations was evaluated in gastric myocytes. The ratio was $\mathrm{Rb}^{+}: \mathrm{K}^{+}: \mathrm{Cs}^{+}: \mathrm{Na}^{+}: \mathrm{Li}^{+}=1.1: 1.1: 1.0: 0.98: 0.8$ with a negligible anionic component ${ }^{[47]}$. However, the amplitude of the inward current was largest with $\mathrm{Cs}^{+}$as the main permeant cation, and smallest with $\mathrm{Na}^{+}$(ie, the rank order was $\mathrm{Cs}^{+}>\mathrm{K}^{+}>\mathrm{Li}^{+}>$ $\left.\mathrm{Na}^{+}\right)$, and unitary conductance was in the order $\mathrm{Cs}^{+}(34 \mathrm{pS})>$ $\mathrm{Na}^{+}(25 \mathrm{pS})>\mathrm{Li}^{+}(21 \mathrm{pS})^{[47]}$.

Nonstationary noise analysis of $\mathrm{m} I_{\mathrm{CAT}}$ induced by intracellular perfusion of GTP $\gamma \mathrm{S}$ in ileal myocytes suggested a mean channel open probability $\left(P_{\mathrm{O}}\right)$ of 0.48 (at $-40 \mathrm{mV}$ during maximal conductance activation) and a total number of channels $(n)$ of approximately $750^{[48]}$. Similar values $\left(P_{\mathrm{O}}=0.43\right.$ and $N=830$ ) were derived from direct single channel measurements in outside-out patches exposed to $50 \mu \mathrm{mol} / \mathrm{L}$ carbachol, suggesting channel density on average of one channel per 6.45 $\mu^{2[49]}$. The channels appear to be clustered as two-thirds of patches were "blank" and approximately $20 \%$ of patches had 2-7 active channels. This uneven distribution of active channels in membrane fragments might reflect not only clustering of the channels themselves, but also a tight co-localization of $\mathrm{mAChR}$ and associated signaling molecules.

In ileal myocytes, the agonist concentration dependence of the channel activation is characterized by a mean $\mathrm{EC}_{50}$ value of $7.6 \mu \mathrm{mol} / \mathrm{L}^{[31]}$. The range of carbachol concentration over which cationic conductance increases in these single isolated cells is thus identical to that measured in the intact tissue ${ }^{[15]}$. Although in different cells the $\mathrm{EC}_{50}$ values varied from approximately 1 to $30 \mu \mathrm{mol} / \mathrm{L}$, their frequency distribution was normal. Thus, within the cell population there seem to be no subgroups of cells, which would differ in their sensitivity to carbachol. Notably, the depolarizing effect of muscarinic agonists saturates at a lower agonist concentration, which can be explained by a large functional reserve in this system owing to the high input resistance of GI myocytes.

\section{Pharmacological properties of $\mathrm{m} \mathrm{I}_{\text {CAT }}$}

Selective blockers of the muscarinic cation current are lacking, although a number of other ion channel blockers can efficiently inhibit $\mathrm{m} I_{\text {CAT }}$. These include the following $\mathrm{Ca}^{2+}$ channel blockers ( $\mathrm{IC}_{50}$ values in parentheses): $\mathrm{Zn}^{2+}$ (38 $\mu \mathrm{mol} / \mathrm{L}) ; \mathrm{Cd}^{2+}(98 \mu \mathrm{mol} / \mathrm{L}) ; \mathrm{Ni}^{2+}(131 \mu \mathrm{mol} / \mathrm{L}) ; \mathrm{Co}^{2+}(700 \mu \mathrm{mol} / \mathrm{L}) ;$ and $\mathrm{Mn}^{2+}(1 \mathrm{mmol} / \mathrm{L})^{[40,45,50,51]}$. Their blocking action is practically voltage-independent, with little change in the reversal potential or sensitivity to the agonist. $\mathrm{K}^{+}$channel or- ganic blockers inhibit cationic current in a voltage-dependent manner, with quinidine being the most potent $\left(\mathrm{IC}_{50}=0.25\right.$ $\mu \mathrm{mol} / \mathrm{L})$, followed by quinine $(1.0 \mu \mathrm{mol} / \mathrm{L}), 4$-aminopyridine $(3.3 \mathrm{mmol} / \mathrm{L}), \mathrm{TEA}^{+}(4.1 \mathrm{mmol} / \mathrm{L})$, and procaine $(1-5$ $\mathrm{mmol} / \mathrm{L})^{[40,52-54]}$. Caffeine, a $\mathrm{Ca}^{2+}$-releasing agent, also blocks cationic current $(\sim 10 \mathrm{mmol} / \mathrm{L})^{[53]}$. Diphenylamine-2-carboxylate derivatives (DCDPC and flufenamic acid) strongly inhibit $\mathrm{Ca}^{2+}$-activated cationic channels and $\mathrm{Cl}^{-}$channels, and block $\mathrm{m} I_{\text {CAT }}$ with $\mathrm{IC}_{50}$ values of approximately $30 \mu \mathrm{mol} / \mathrm{L}^{[53]}$.

SK\&F 96365, a common blocker of receptor-stimulated $\mathrm{Ca}^{2+}$ entry, showed a most peculiar blocking action on $\mathrm{mI}_{\mathrm{CAT}}$, which was time- and voltage-dependent producing concomitant alteration of the steady-state current-voltage ( $I-V)$ relationship ${ }^{[55]}$. At a constant SK\&F 96365 concentration the degree of the $m I_{\text {CAT }}$ inhibition was a sigmoidal function of the membrane voltage with a slope factor of approximately 13 $\mathrm{mV}$ and half-maximal inhibition at approximately $30 \mathrm{mV}$. This unique time- and voltage-dependent mode of SK\&F 96365 action on the native channel might be very useful for its identification in future comparative expression studies. Extracellular spermine and putrescine also blocked $\mathrm{m} I_{\mathrm{CAT}}$ in a voltage-dependent manner with $\mathrm{IC}_{50}$ values (at $-40 \mathrm{mV}$ ) of approximately 1 and $5 \mathrm{mmol} / \mathrm{L}$, respectively ${ }^{[56]}$. This inhibitory action was relieved by membrane depolarization. Intracellular polyamines also inhibited $\mathrm{mI}_{\mathrm{CAT}}$, but its complex Nshaped activation curve did not seem to result from this effect.

\section{Voltage dependence of $\mathrm{m} \mathrm{I}_{\mathrm{CAT}}$ : synergy with $\mathrm{G}$ protein activation}

$\mathrm{m} I_{\mathrm{CAT}}$ that is evoked in GI myocytes either by $\mathrm{mAChR}$ activation or by intracellular application of GTP $\gamma \mathrm{S}$ in the absence of an agonist has interesting voltage-dependent properties. Its steady-state $I-V$ curve shows double rectification around the reversal potential, and with hyperpolarization the current first increases in keeping with an increase in the driving force, reaches a maximum at approximately -40 to $-50 \mathrm{mV}$, then declines. In some cells $\mathrm{m} \mathrm{I}_{\mathrm{CAT}}$ can even be completely lost when the membrane potential reaches approximately -100 to $-120 \mathrm{mV}$. By analogy with the classical voltage-gated channels, a Boltzmann relationship was often used to describe this voltage-dependence (although its usefulness is limited to negative potentials because the activation curve is overall N-rather than S-shaped), and a two-state (one open and one closed) model was introduced as an underlying mechanism ${ }^{[57]}$. The voltage dependence was characterized by the potential of half-maximal activation of approximately $-50 \mathrm{mV}$ and the slope factor in the range $15-27 \mathrm{mV}^{[57-59]}$. A receptor-operated cationic current 
displaying a similar U-shaped $I-V$ relationship at negative potentials was described in many different smooth muscle tissues $^{[38,40,45,51,52,54,60,61]}$, suggesting that this current is ubiquitous.

During a negative voltage step the current increased instantaneously and proportionally to the increase in the driving force, but then it exponentially relaxed to a smaller steadystate level with a time constant in the order of 50-150 ms which decreased with hyperpolarization ${ }^{[52,57]}$. After repolarization to the holding potential, monoexponentially decaying tail currents were observed.

This behavior is characteristic for voltage-gated ion channels and thus consistent with the idea that some charged groups ("voltage sensor") influence the channel $P_{\mathrm{O}}$. However, as this channel is primarily gated by $\mathrm{mAChR}$ and associated $\mathrm{G}$ protein activation (ie, depolarization by itself hardly activates it), the gating mechanisms could be undoubtedly far more complex. Indeed, it turned out that the voltage range of the channel activation was one of the primary targets of $\mathrm{G}$ protein activation ${ }^{[59]}$. In some cells even a completely linear $I-V$ curve could be seen over the range of 0 to $-120 \mathrm{mV}$ at high agonist concentration $(300 \mu \mathrm{mol} / \mathrm{L}$ carbachol) or following sufficiently long $200 \mu \mathrm{mol} / \mathrm{L}$ GTP $\gamma \mathrm{S}$ infusion. With desensitization, however, the $I-V$ relationship again acquired its usual U-shape ${ }^{[62]}$. Associated with these changes in the $I-V$ shape, there was also a pronounced change in the rate of relaxation of the current during a voltage step. The physiological significance of this $\mathrm{G}$ protein modulation of the cationic channel voltage dependence is obviously in creating a system where there is cross-talk between $\mathrm{mAChR} / \mathrm{G}$ protein activation, channel opening and membrane depolarization.

This interesting "interchangeability" of the effects of membrane potential and $G$ protein activation on channel gating suggests that a strong synergy exists in this system, to an extent where it is difficult to distinguish between the primary and secondary gating stimuli. Indeed, if, instead of using the Boltzmann relation, $\mathrm{mI}_{\mathrm{CAT}}$ amplitude measured at different potentials is plotted against the agonist concentration and data is fitted by the Hill relation, this reveals the main effect of voltage on the agonist sensitivity, characterized by approximately $80 \% \mathrm{EC}_{50}$ reduction between -120 and $80 \mathrm{mV}^{[63,64]}$. There is also a significant reduction of the latency of the response, acceleration of the agonist on-rate and reduction of the off-rate associated with membrane depolarization. All these observations imply that some ligands produced by mAChR stimulation might interact with the channel in a voltage-dependent manner, rather than there being a classical "voltage sensor" in its structure. In con- nection with this, it is notable that the channel voltage range of activation is also affected by PLC- $\beta$ inhibition and by $\left[\mathrm{Ca}^{2+}\right]_{\mathrm{i}}^{[65,66]}$. This is relevant to the recently proposed linkage between $\mathrm{mI}_{\mathrm{CAT}}$ and TRPC4/5 channels ${ }^{[17,67-69]}$ as TRP channels are generally lacking the full complement of charged amino acids (ie, classical "voltage sensors") in the S4 segment $^{[70]}$.

It should be noted, however, that recent single channel studies began to reveal intrinsic voltage-dependent channel gating, which was not evident in previous whole-cell measurements. Although membrane depolarization alone could hardly induce any significant whole-cell current, in single channel measurements spontaneous background channel activity was revealed. It was characterized by long closings and only brief openings consistent with the $\mathrm{C} 1-\mathrm{O} 1$ gating (see below) and it was channel gating in this pair of states that showed the most prominent voltage dependence ${ }^{[49,71]}$. Membrane depolarization strongly accelerated these spontaneous openings (the main effect of voltage is to shorten the long closed state of the channel) although they remain too brief to generate any measurable whole-cell current.

\section{Signal transduction: synergy between $M_{2}$ and $M_{3}$ receptors}

Early studies have shown that $\mathrm{m} I_{\mathrm{CAT}}$ in GI myocytes can be almost completely blocked by treating the cells with pertussis toxin ${ }^{[25,27,28,35]}$ which raised an immediate possibility that it was the $\mathrm{M}_{2}$ receptor subtype that triggered $\mathrm{mI}$ CAT. Consistent with this, experiments with the use of antibodies against the $\alpha$-subunits of a range of G-proteins pinpointed $\mathrm{G}_{\alpha_{0}}$ involvement and excluded the role of the $\beta \gamma$-subunits of G-proteins ${ }^{[26,29]}$.

Subsequent pharmacological studies confirmed the primary role of $\mathrm{M}_{2}$ receptor activation in $\mathrm{mI}_{\mathrm{CAT}}$ generation, but, quite unexpectedly, $\mathrm{m} I_{\mathrm{CAT}}$ was also found to be strongly dependent on the activation of the $\mathrm{M}_{3}$ receptor subtype ${ }^{[30-35,72]}$. This was evident from the effects of $\mathrm{M}_{3}$-selective muscarinic antagonists, which, particularly at low concentrations, did not displace the agonist curve but produced a substantial reduction of the maximum cationic conductance ${ }^{[31,32]}$.

One well established mechanism of the possible $\mathrm{M}_{3}$ receptor convergence on the $\mathrm{M}_{2}$-activated $\mathrm{mI}_{\mathrm{CAT}}$ is a $\left[\mathrm{Ca}^{2+}\right]_{\mathrm{i}}$ rise due to $\mathrm{InsP}_{3}$-induced $\mathrm{Ca}^{2+}$ release. This is operational because cation channel opening is strongly potentiated by intracellular $\mathrm{Ca}^{2+}$. A better documented example of such a role of $\mathrm{M}_{3}$ receptors in $\mathrm{m} I_{\mathrm{CAT}}$ modulation is concurrent $\mathrm{m} I_{\mathrm{CAT}}$ and $\left[\mathrm{Ca}^{2+}\right]_{\mathrm{i}}$ oscillations ${ }^{[23,66,73-76]}$. However, even when this $\mathrm{Ca}^{2+}$-mediated link is disabled, for example, by strongly buffering $\left[\mathrm{Ca}^{2+}\right]_{\mathrm{i}}, \mathrm{M}_{3}$-dependent regulation of $\mathrm{mI} I_{\mathrm{CAT}}$ is 
stillpresent $\mathrm{t}^{[31,32]}$ and a significant correlation of muscarinic agonist potencies between the $\mathrm{M}_{2} / \mathrm{mI} I_{\mathrm{CAT}}$ and the $\mathrm{M}_{3} / \mathrm{PLC}-\beta /$ InsP $_{3}$ systems still exists ${ }^{[34]}$.

The interaction between $\mathrm{M}_{2}$ and $\mathrm{M}_{3}$ receptors in producing $\mathrm{m} I_{\mathrm{CAT}}$ shows up somewhat differently in guinea pig gastric myocytes under "unclamped" $\left[\mathrm{Ca}^{2+}\right]_{\mathrm{i}}$ conditions, in which case the $\mathrm{M}_{3}$ selective blockade does not reduce the maximal response, but instead reduces the agonist sensitivity of the $\mathrm{M}_{2}$-induced current ${ }^{[35]}$.

\section{Intracellular $\mathrm{Ca}^{2+}$ dependence of $\mathrm{m} \mathrm{IAT}_{\mathrm{CAT}}$ : synergy with the PLC- $\beta /$ Ins $\mathrm{P}_{3}$ system}

The $\left[\mathrm{Ca}^{2+}\right]_{\mathrm{i}}$-dependency aspect of $\mathrm{m} I_{\mathrm{CAT}}$ regulation has received perhaps the most attention. An elevation of $\left[\mathrm{Ca}^{2+}\right]_{i}$ by itself is somewhat insufficient to induce $\mathrm{mI}_{\mathrm{CAT}}$, but when the channel is primed by an activated $\mathrm{G}$ protein its opening is greatly potentiated by a rise in $\left[\mathrm{Ca}^{2+}\right]_{\mathrm{i}}^{[23,24,30,38,40,44,60,73,74,76]}$. However, when $\left[\mathrm{Ca}^{2+}\right]_{\mathrm{i}}$ is abnormally low (eg, at a high EGTA or BAPTA concentration inside the cell) no or very little channel activation is possible even at maximal $\mathrm{mAChR}$ stimulation ${ }^{[24,44,61,74]}$. Thus, it follows that intracellular $\mathrm{Ca}^{2+}$ has both a permissive and a facilitating effect on channel gating.

With low $\left[\mathrm{Ca}^{2+}\right]_{\mathrm{i}}$ buffering, mAChR stimulation or direct $\mathrm{G}$ protein activation by intracellular GTP $\gamma \mathrm{S}$ produces $\left[\mathrm{Ca}^{2+}\right]_{\mathrm{i}}$ oscillations, which result from periodic release of $\mathrm{Ca}^{2+}$ from the intracellular stores. These cause temporally closely related oscillations of the cationic current ${ }^{[23,27,74]}$; the frequency of these oscillations is strongly modulated by $\mathrm{Ca}^{2+}$ influx ${ }^{[77]}$. Interestingly, $\left[\mathrm{Ca}^{2+}\right]_{\mathrm{i}}$ rise results in a considerable negative shift of the activation curve by approximately $30 \mathrm{mV}^{[64]}$, that is, linearization of the $I-V$ relationship occurs similarly to that caused by increasing receptor stimulation. Both $\left[\mathrm{Ca}^{2+}\right]_{\mathrm{i}}$ and $\mathrm{mI} I_{\text {CAT }}$ oscillations are similarly sensitive to $\mathrm{Ca}^{2+}$ store depletion produced by $\mathrm{InsP}_{3}$, thapsigargin or cyclopiazonic acid, as well as to the $\operatorname{InsP}_{3}$ receptor blocker heparin ${ }^{[23,30,74,77,78]}$.

The relationship between $\left[\mathrm{Ca}^{2+}\right]_{\mathrm{i}}$ and $\mathrm{m} I_{\mathrm{CAT}}$ amplitude was quantified by buffering $\left[\mathrm{Ca}^{2+}\right]_{\mathrm{i}}$ at different levels using either EGTA $/ \mathrm{Ca}^{2+}$ or BAPTA $/ \mathrm{Ca}^{2+}$ mixtures or, in the same cell, by varying the amount of $\mathrm{Ca}^{2+}$ entering the cell through $\mathrm{VDCC}^{[24,64,65]}$. These experiments revealed a calcium $\mathrm{EC}_{50}$ value of approximately $200-400 \mathrm{nmol} / \mathrm{L}$. However, prolonged $\left[\mathrm{Ca}^{2+}\right]_{\mathrm{i}}$ elevation $\left(\mathrm{eg},\left[\mathrm{Ca}^{2+}\right]_{\mathrm{i}}\right.$ buffering at $\left.500 \mathrm{nmol} / \mathrm{L}\right)$ caused strong $\mathrm{m} I_{\mathrm{CAT}}$ desensitization even if the current was induced by GTP $\gamma \mathrm{S}$ without receptor stimulation ${ }^{[64,79]}$, an effect presumably related to PKC activation ${ }^{[80]}$. At the single channel level, this biphasic $\left[\mathrm{Ca}^{2+}\right]_{\mathrm{i}}$ dependence is seen as a peak of channel $P_{\mathrm{O}}$ with $100 \mathrm{nmol} / \mathrm{L} \mathrm{Ca}^{2+}$ at the internal side of the membrane compared with either 30 or $500 \mathrm{nmol} / \mathrm{L}\left[\mathrm{Ca}^{2+}\right]_{i}$; no effect of $\left[\mathrm{Ca}^{2+}\right]_{\mathrm{i}}$ on the unitary conductance was observed ${ }^{[81]}$.

Interestingly, $\mathrm{m} I_{\mathrm{CAT}}$ was found to be most responsive to rapid changes in $\left[\mathrm{Ca}^{2+}\right]_{\mathrm{i}}$ caused by abrupt flash photolysis release of $\mathrm{InSP}_{3}$, but was rather insensitive to $\left[\mathrm{Ca}^{2+}\right]_{i}$ elevation produced in small steps by NP-EGTA photorelease ${ }^{[76]}$. Moreover, a striking difference was found between the effects of flash-released $\mathrm{InsP}_{3}$ and caffeine applications, as $\mathrm{Ca}^{2+}$ release through ryanodine receptors (RyR) failed to potentiate $\mathrm{m} I_{\text {CAT }}$. This can be attributed, at least in part, to the differential distribution of $\operatorname{InsP}_{3}$ and RyRs within a smooth muscle myocyte, as type $\mathrm{I} \mathrm{InsP}_{3}$ receptors were predominantly localized in a close juxtaposition to the plasma membrane but RyRs were mostly found in the central region of the cell ${ }^{[76]}$. Even more intriguingly, $\mathrm{Ca}^{2+}$ sparks induced STOCs but failed to potentiate $\mathrm{m} I_{\text {CAT }}$. This dependence of $\mathrm{m} I_{\mathrm{CAT}}$ on a global rather than local $\left[\mathrm{Ca}^{2+}\right]_{\mathrm{i}}$ rise is similar to differential activation of STOCs and $I_{\mathrm{Cl}(\mathrm{Ca})}$ by $\mathrm{Ca}^{2+}$ sparks and waves, respectively, in rat portal vein myocytes ${ }^{[82]}$.

Thus, one possibility is that the spatiotemporal pattern of the calcium signal is an important determinant of the $\left[\mathrm{Ca}^{2+}\right]_{\mathrm{i}}^{-}$ dependent modulation of $\mathrm{m} I_{\mathrm{CAT}}$. However, the recently proposed link between $\mathrm{m} I_{\mathrm{CAT}}$ and TRPC4/5 proteins ${ }^{[67-69]}$ raises other intriguing possibilities and questions. In different studies, TRPC4 and TRPC5 have been shown to form either store- or receptor-operated cation channels that can be activated with or without the involvement of $\operatorname{InsP}_{3}{ }^{[83,84]}$. Overall, many properties of $\mathrm{m} I_{\mathrm{CAT}}$ are highly similar to receptor-operated cation channels formed by TRPC4 and TRPC5, which includes the complex effects of intracellular $\mathrm{Ca}^{2+}$ (ie, permissive, potentiating and desensitizing action $)^{[85]}$.

Further similarities of $\mathrm{mI}_{\mathrm{CAT}}$ and TRPC4/5 activation include regulation through the PLC pathway. Several recent studies revealed the importance of PLC in $\mathrm{m} I_{\mathrm{CAT}}$ activation $^{[66,68,86]}$. In murine gastric myocytes the current was inhibited by the anti- $\mathrm{G}_{\mathrm{q} / 11}$ antibody, the PLC blocker U-73122 and the IICR inhibitor 2-APB, but was insensitive to the anti$\mathrm{G}_{\mathrm{o}}$ antibody ${ }^{[68]}$. By contrast, in guinea pig ileal myocytes PLC inhibition abolished $\mathrm{mI}_{\mathrm{CAT}}$ without the involvement of DAG, InsP ${ }_{3}$ or $\mathrm{Ca}^{2+}$ store depletion ${ }^{[66,86]}$. Strikingly, the anti$\mathrm{G}_{\mathrm{q} / 11}$ antibody was ineffective in ileal myocytes ${ }^{[29,86]}$, raising questions about the PLC isoforms involved in $\mathrm{mI}_{\mathrm{CAT}}$ activation in these cells. One possibility is that $\mathrm{M}_{2}$ receptors can also couple to PLC activation through $\beta \gamma$ dimers released from $\mathrm{G}_{\mathrm{i} / \mathrm{o}}$ proteins ${ }^{[87,88]}$ and this link can obscure the effects of the anti- $\mathrm{G}_{\mathrm{q} / 11}$ antibody. However, such a role of $\beta \gamma$-subunits would be inconsistent with the lack of the effects of the G $\beta$ antibody as well as $\beta \gamma$ dimer infusion in the same cells ${ }^{[29]}$. Even more importantly, recent studies have shown that $\mathrm{mI}_{\mathrm{CAT}}$ is lacking in cells isolated from $\mathrm{M}_{2}$ or $\mathrm{M}_{3}$ knockout mouse ${ }^{[89]}$, 
but if the $\mathrm{M}_{2} / \mathrm{PLC}$ linkage were sufficient to support its activation the current would be present in the $\mathrm{M}_{3}$ subtype knockout mouse. Tyrosine kinase-dependent pathways also play a role in $\mathrm{m} I_{\mathrm{CAT}}$ regulation ${ }^{[90]}$, therefore the role of receptor tyrosine kinases that couple to PLC- $\gamma$ deserves further investigation. Finally, there is a possibility that some soluble PLC isoforms are involved in $\mathrm{m} I_{\mathrm{CAT}}$ activation, which are not inhibited by $\mathrm{G}$ protein antibodies ${ }^{[91]}$.

The role of DAG as a possible intermediary between PLC activation and $\mathrm{m} I_{\mathrm{CAT}}$ was also addressed in these studies, however both in gastric and ileal myocytes OAG, an analogue of DAG, failed to induce any significant current. Thus, the signalling events downstream of PLC activation remain unknown. It is also unclear how the PLC pathway activates TRPC4/5 channels; one possibility that needs to be explored is that the channels are activated by the depletion of the PLC substrate, like $\mathrm{PIP}_{2}$, rather than by the PLC products. However, PLC generates other potential signalling molecules, such as poly-unsaturated fatty acids (PUFAs), and the role of the numerous lipid messengers in $\mathrm{m} I_{\mathrm{CAT}}$ activation remains to be explored.

It also remains unknown whether intracellular $\mathrm{Ca}^{2+} \mathrm{di}-$ rectly binds to the channel protein or exerts its modulatory effect by an intermediate enzymatic step. Following agonist application there is a considerable latency of approximately $230 \mathrm{~ms}$ and a time lag of approximately $1.2 \mathrm{~s}$ between peaks of $\left[\mathrm{Ca}^{2+}\right]_{\mathrm{i}}$ and $\mathrm{m} I_{\mathrm{CAT}}$ during the first $\mathrm{Ca}^{2+}$ wave, but subsequent $\left[\mathrm{Ca}^{2+}\right]_{\mathrm{i}}$ oscillations are mirrored by $\mathrm{m} I_{\mathrm{CAT}}$ very closely ${ }^{[76]}$. These kinetics data thus suggest that channel $\mathrm{Ca}^{2+}$ "priming", or permissive effect, might be indirect, but once established the channel might be regulated by $\mathrm{Ca}^{2+}$ in a more direct manner. Possible intermediates include calmodulin and myosin light chain kinase ${ }^{[61,92]}$. It should be also noted that the cAMP/PKA pathway is not involved in $\mathrm{mI}_{\mathrm{CAT}}$ regulation ${ }^{[66]}$.

\section{Channel gating mechanism: cyclical transitions between 4 connected open and closed states}

Summarizing the signal transduction pathways, the muscarinic cation channel is a voltage- and $\mathrm{Ca}^{2+}$-sensitive channel gated by G $\alpha$-GTP in a PLC-dependent manner, as shown in Figure 1. Various ligands could produce kinetically distinct channel conformations, therefore it was reasonable to expect a similarly complex channel gating mechanism. Single channel activity was studied in membrane patches isolated from guinea pig and murine ileal and gastric myocytes. Cation channels with voltage-dependent properties consistent with the whole-cell current behavior had unitary conduc- tances of $35 \mathrm{pS}$ (guinea pig gastric myocytes ${ }^{[47]}$ ), $57 \mathrm{pS}$ (guinea pig ileal myocytes ${ }^{[49]}$ ) and $70 \mathrm{pS}$ (murine ileal myocytes $\left.^{[81]}\right)$. These differences to some extent are related to different ion conditions, for example, for recordings in guinea pig gastric myocytes $2 \mathrm{mmol} / \mathrm{L}$ external $\mathrm{Ca}^{2+}$ was used, and in murine ileal myocytes an addition of $2.5 \mathrm{mmol} / \mathrm{L} \mathrm{Ca}^{2+}$ to the external solution was shown to reduce unitary conductance from 70 to $46 \mathrm{pS}$.

In guinea pig ileal myocytes, the $57 \mathrm{pS}$ channel has at least 8 kinetically distinct states, 4 open and 4 closed. Analysis of adjacent dwell times revealed strong correlations, which suggested connections between them, as shown in Figure 2. These are features present in many other ligandgated ion channels, such as $\mathrm{nAChR}$ or $\mathrm{BK}_{\mathrm{Ca}}$ channels. One unusual property of the $\mathrm{mAChR}$-gated channel is the presence of prominent regular cycles of $P_{\mathrm{O}}$ that occurred due to a variable number of long openings between consecutive long shuttings, or, in other words, due to periodical shifts of gating between the two main modes, the low- $P_{\mathrm{O}}$ mode in the $\mathrm{C} 1-\mathrm{O} 1$ states (long closings and brief openings) and the high- $P_{\mathrm{O}}$ mode in the $\mathrm{C} 4-\mathrm{O} 4$ states (conversely, long openings and brief closings).

Presently the origin of the channel voltage dependence in this channel mechanism is clear but the nature of ligands stabilizing various open states needs further exploration. Thus, membrane potential affects vertical transitions but does not cause any net horizontal redistribution between the states. Interestingly, as the channel activity progresses from low- to high- $P_{\mathrm{O}}$ mode (ie, gating shifts from left to right in Figure 2) channel gating becomes less voltage-dependent. Thus, the $\mathrm{C} 1$ dwell time shows the strongest voltage dependence, but the $\mathrm{C} 4$ mean dwell time remains unaltered at potentials between -120 and $-10 \mathrm{mV}$.

Considering how channel ligands could produce these various kinetically distinct channel conformations, it is important to note that channel $P_{\mathrm{O}}$ according to this scheme increases in 3 stages, and that the $\mathrm{O} 1$ and $\mathrm{O} 2$ states could hardly generate any significant integral current as their joint contribution to the overall $P_{\mathrm{O}}$ is only $3 \%$. Thus, any signals that can induce only these 2 open states would produce a tiny whole-cell current; nevertheless, such signals might be crucially important for further progression of the channel activation towards the $\mathrm{C} 3-\mathrm{O} 3$ and $\mathrm{C} 4-\mathrm{O} 4$ gating. The $\mathrm{O} 3$ and $\mathrm{O} 4$ states were estimated to generate, respectively, $24 \%$ and $73 \%$ of the whole-cell current at maximal receptor activation.

Because channel gating similar to the $\mathrm{C} 1-\mathrm{O} 1$ gating is seen in the absence of mAChR activation it seems to be an intrinsic voltage-dependent channel property. Based on the 


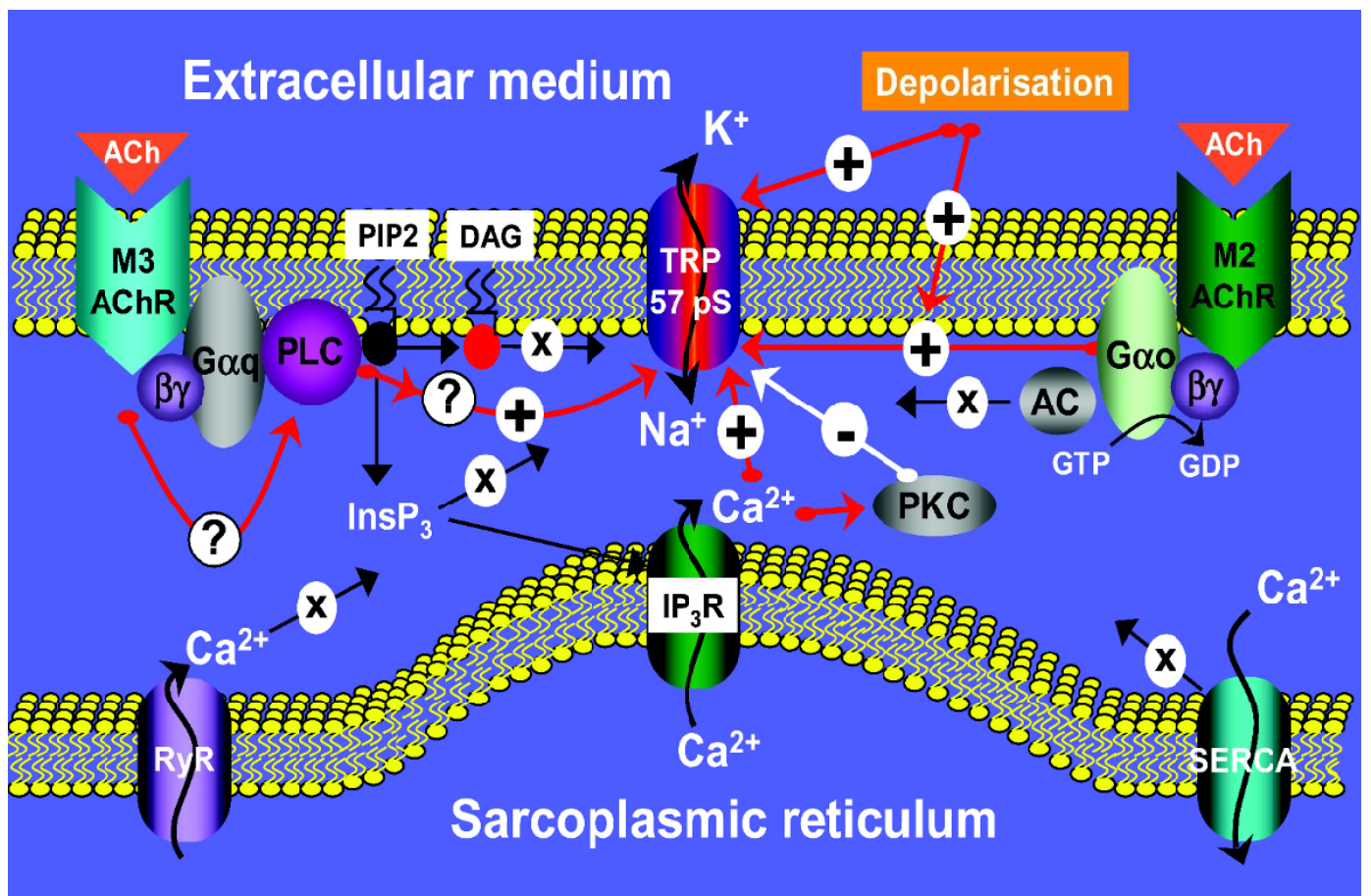

Figure 1. Multiple signal transduction pathways linking $\mathrm{M}_{2}$ and $\mathrm{M}_{3}$ receptor activation to TRP-like cation channel opening in GI myocytes. Many activation pathways $(+)$ act in synergy but the precise nature of their interaction remains unclear, particularly regarding the possibility of direct $\mathrm{G}_{\alpha 0}-\mathrm{GTP}$ and $\mathrm{Ca}^{2+}$ binding to the channel, the enigmatic $\mathrm{M}_{3}$ or $\mathrm{M}_{2}$ link to the PLC activation bypassing the $\mathrm{G}_{\mathrm{q} / 11}$ protein, and the events downstream of PLC activation. $\mathrm{Ca}^{2+}$-dependent activation of PKC appears to be the main mechanism of $\mathrm{mI} \mathrm{CAT}_{\mathrm{C}}$ desensitization (-). However, several pathways do not seem to play a role in $\mathrm{m}_{\mathrm{CAT}}$ regulation (x); these include DAG, $\beta \gamma$-dimers of $\mathrm{G}$ proteins, $\mathrm{Ca}^{2+}$ store depletion (eg, SERCA inhibition), $\mathrm{Ca}^{2+}$ release through RyRs, direct action of $\mathrm{InsP}_{3}$ and adenylyl cyclase (AC) inhibition.

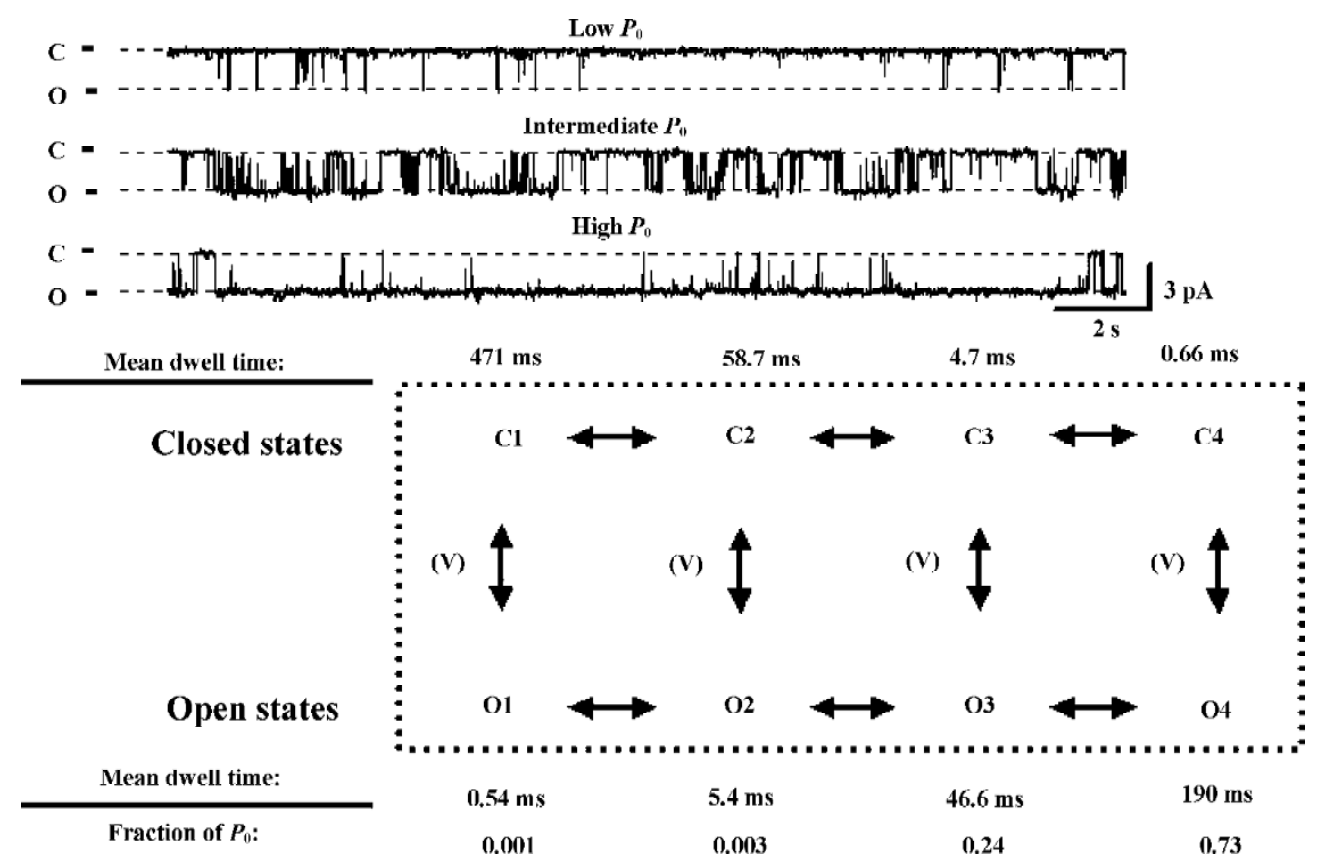

Figure 2. Channel gating mechanism with mean dwell times as measured in outside-out patches held at $-40 \mathrm{mV}$ and exposed to external 50 $\mu \mathrm{mol} / \mathrm{L}$ carbachol or internal $200 \mu \mathrm{mol} / \mathrm{L}$ GTP $\gamma \mathrm{S}^{[49]}$. Typical examples of channel gating in the low (C1-O1), intermediate (C2-O2 and C3-O3) and high (C4-O4) $P_{\mathrm{O}}$ modes are shown. C, closed; O, open. 
above considerations, one can also suggest that any permissive effects (eg, $\left[\mathrm{Ca}^{2+}\right]_{\mathrm{i}}$, the PLC/InsP $\mathrm{P}_{3}$ system) are fulfilled through the occurrence of the intermediate states, such as $\mathrm{O} 2$, whereas full channel activation in the longer $\mathrm{O} 3$ and $\mathrm{O} 4$ open states requires cooperative interactions of all channel ligands, including G $\alpha$-GTP. This hypothesis can mechanistically account for many permissive and major synergistic links in $\mathrm{m} I_{\mathrm{CAT}}$ activation, which were discussed in this review, and might offer a useful model for future experimental tests.

\section{Conclusion}

The past decade has led to significant progress in our understanding of the roles of $\mathrm{M}_{2}$ and $\mathrm{M}_{3}$ receptors in GI smooth muscle excitation through the detailed studies of $\mathrm{m} I_{\mathrm{CAT}}$, a primary depolarizing current. Many important synergies have been revealed, including cross-talk between receptor subtypes, $\mathrm{Ca}^{2+}$ and $\mathrm{InsP}_{3}$, and the crucial roles of both $\mathrm{G}_{\mathrm{o}}$ and PLC- $\beta$ activation. However, exactly how $\mathrm{G}_{\mathrm{o}}$ protein is involved in $\mathrm{m} I_{\text {CAT }}$ generation and the activator in the PLC pathway remain unknown. PLCs are complexly regulated by various receptors, and it appears that they are one of the most important merging points in the pathways linking $\mathrm{M}_{2}$ and $\mathrm{M}_{3}$ receptors to cation channels. Synergistic mechanisms also exist in receptor-mediated PLC activation, thus more research is needed on the PLC-dependent modulation of $\mathrm{m} I_{\mathrm{CAT}}$. The mouse model of $\mathrm{m} I_{\mathrm{CAT}}$ has been recently validated $^{[93]}$, and it shows all the essential features of the complex regulation of $\mathrm{mI}_{\mathrm{CAT}}$ discussed in this review. Thus, future significant progress can be expected through the studies of $\mathrm{m} I_{\mathrm{CAT}}$ in genetically modified mice lacking certain receptors or other putative elements of the complexly intervened signal transduction pathways. The sequence of ligand interactions with the channel also remains unknown, but if established it will provide the most conclusive evidence for the specific roles of $\mathrm{M}_{2}$ and $\mathrm{M}_{3}$ receptors in smooth muscle excitation. The recently proposed TRPC4/5 connection raises further challenging questions, for example, the reasons why heterologously expressed TRPC $4 / 5$ channels can be activated by $\mathrm{G}_{\mathrm{q} / 11}$-coupled receptors alone, but the native channel requires simultaneous activation of $\mathrm{M}_{2}$ receptor and $\mathrm{G}_{\mathrm{o}}$.

\section{References}

1 Bolton TB. Mechanisms of action of transmitters and other substances on smooth muscle. Physiol Rev 1979; 59: 606-718.

2 Kunze WAA, Furness JB. The enteric nervous system and regulation of intestinal motility. Annu Rev Physiol 1999; 61: 117-42.

3 Sanders KM. G protein-coupled receptors in gastrointestinal physiology. IV. Neural regulation of gastrointestinal smooth muscle. Am J Physiol 1998; 275: G1-7.

4 Sanders KM, Ordog T, Ward SM. Physiology and pathophysiology of the interstitial cells of Cajal: from bench to bedside. IV. Genetic and animal models of GI motility disorders caused by loss of interstitial cells of Cajal. Am J Physiol 2002; 282: G747-56.

5 Bolton TB, Prestwich SA, Zholos AV, Gordienko DV. Excitation-contraction coupling in gastrointestinal and other smooth muscles. Annu Rev Physiol 1999; 61: 85-115.

6 Kuriyama H, Kitamura K, Itoh T, Inoue R. Physiological features of visceral smooth muscle cells, with special reference to receptors and ion channels. Physiol Rev 1998; 78: 811-920.

7 Eglen RM, Reddy H, Watson N, Challiss RA. Muscarinic acetylcholine receptor subtypes in smooth muscle. Trends Pharmacol Sci 1994; 15: 114-9.

8 Eglen RM. Muscarinic receptor subtype pharmacology and physiology. Prog Med Chem 2005; 43: 105-36.

9 Eglen RM, Hegde SS, Watson N. Muscarinic receptor subtypes and smooth muscle function. Pharmacol Rev 1996; 48: 531-65.

10 Bülbring E. Membrane potential of smooth muscle fibres of the taenia coli of the guinea-pig. J Physiol 1954; 125: 302-15.

11 Bülbring E. Correlation between membrane potential, spike discharge and tension in smooth muscle. J Physiol 1955; 128: 200-21.

12 Bülbring E, Kuriyama H. Effect of changes in ionic environment on the action of acetylcholine and adrenaline on the smooth muscle cells of guinea-pig taenia coli. J Physiol 1963; 166: 59-74.

13 Burnstock G. The effects of acetylcholine on membrane potential, spike frequency, conduction velocity and excitability in the taenia coli of the guinea-pig. J Physiol 1958; 143: 165-82.

14 Shuba MF. Effects of acetylcholine on physical electrotonus of smooth muscle. Fiziol Zh 1962; 8: 449-55.

15 Bolton TB. The depolarizing action of acetylcholine or carbachol in intestinal smooth muscle. J Physiol 1972; 220: 647-71.

16 Bolton TB. Effects of stimulating the acetylcholine receptor on the current-voltage relationships of the smooth muscle membrane studied by voltage clamp of potential recorded by microelectrode. J Physiol 1975; 250: 175-202.

17 So I, Kim KW. Nonselective cation channels activated by the stimulation of muscarinic receptors in mammalian gastric smooth muscle. J Smooth Muscle Res 2003; 39: 231-47.

18 Brading AF, Sneddon P. Evidence for multiple sources of calcium for activation of the contractile mechanism of guinea-pig taenia coli on stimulation with carbachol. Br J Pharmacol 1980; 70: $229-40$

19 Parekh AB, Brading AF. The sources of calcium for carbacholinduced contraction in the circular smooth muscle of guinea-pig stomach. Br J Pharmacol 1991; 104: 412-8.

20 Hishinuma S, Hongo I, Matsumoto Y, Narita F, Kurokawa M. Contrasting effects of carbachol, McN-A-343 and AHR-602 on $\mathrm{Ca}^{2+}$-mobilization and $\mathrm{Ca}^{2+}$-influx pathways in taenia caeci. $\mathrm{Br} \mathrm{J}$ Pharmacol 1997; 122: 985-92.

21 Unno T, Kwon SC, Okamoto H, Irie Y, Kato Y, Matsuyama H, et al. Receptor signaling mechanisms underlying muscarinic agonist-evoked contraction in guinea-pig ileal longitudinal smooth muscle. Br J Pharmacol 2003; 139: 337-50.

22 Berridge MJ, Lipp P, Bootman MD. The versatility and universality of calcium signalling. Nat Rev Mol Cell Biol 2000; 1: 11-21.

23 Pacaud P, Bolton TB. Relation between muscarinic receptor cationic current and internal calcium in guinea-pig jejunal smooth muscle cells. J Physiol 1991; 441: 477-99. 
24 Inoue R, Isenberg G. Intracellular calcium ions modulate acetylcholine-induced inward current in guinea-pig ileum. J Physiol 1990; 424: 73-92.

25 Inoue R, Isenberg G. Acetylcholine activates nonselective cation channels in guinea pig ileum through a $\mathrm{G}$ protein. Am J Physiol 1990; 258: C1173-8.

26 Kim YC, Kim SJ, Sim JH, Cho CH, Juhnn YS, Suh SH, et al. Suppression of the carbachol-activated nonselective cationic current by antibody against alpha subunit of $\mathrm{G}_{\mathrm{o}}$ protein in guineapig gastric myocytes. Pflugers Arch 1998; 436: 494-6.

27 Komori S, Kawai M, Takewaki T, Ohashi H. GTP-binding protein involvement in membrane currents evoked by carbachol and histamine in guinea-pig ileal muscle. J Physiol 1992; 450: 105-26.

28 Pucovsky V, Zholos AV, Bolton TB. Muscarinic cation current and suppression of $\mathrm{Ca}^{2+}$ current in guinea pig ileal smooth muscle cells. Eur J Pharmacol 1998; 346: 323-30.

29 Yan HD, Okamoto H, Unno T, Tsytsyura YD, Prestwich SA, Komori S, et al. Effects of G-protein-specific antibodies and G $\beta \gamma$ subunits on the muscarinic receptor-operated cation current in guinea-pig ileal smooth muscle cells. Br J Pharmacol 2003; 139: $605-15$.

30 Wang YX, Fleischmann BK, Kotlikoff MI. $\mathrm{M}_{2}$ receptor activation of nonselective cation channels in smooth muscle cells: calcium and $\mathrm{G}_{\mathrm{i}} / \mathrm{G}_{0}$ requirements. Am J Physiol 1997; 273: C500-8.

31 Zholos AV, Bolton TB. Muscarinic receptor subtypes controlling the cationic current in guinea-pig ileal smooth muscle. $\mathrm{Br} \mathrm{J}$ Pharmacol 1997; 122: 885-93.

32 Bolton TB, Zholos AV. Activation of $\mathrm{M}_{2}$ muscarinic receptors in guinea-pig ileum opens cationic channels modulated by $\mathrm{M}_{3}$ muscarinic receptors. Life Sci 1997; 60: 1121-8.

33 Unno $\mathrm{T}$, Matsuyama $\mathrm{H}$, Komori S. Interaction between the $\mathrm{M}_{2}$ and $\mathrm{M}_{3}$-receptor subtypes in muscarinic electrical and mechanical responses of intestinal smooth muscles. Neurophysiology 2003; 35: 290-301.

34 Okamoto H, Prestwich SA, Asai S, Unno T, Bolton TB, Komori S. Muscarinic agonist potencies at three different effector systems linked to the $\mathrm{M}_{2}$ or $\mathrm{M}_{3}$ receptor in longitudinal smooth muscle of guinea-pig small intestine. Br J Pharmacol 2002; 135: $1765-75$.

35 Rhee JC, Rhee PL, Park MK, So I, Uhm DY, Kim KW, et al. Muscarinic receptors controlling the carbachol-activated nonselective cationic current in guinea pig gastric smooth muscle cells. Jpn J Pharmacol 2000; 82: 331-7.

36 Beech DJ. Actions of neurotransmitters and other messengers on $\mathrm{Ca}^{2+}$ channels and $\mathrm{K}^{+}$channels in smooth muscle cells. Pharmacol Ther 1997; 73: 91-119.

37 Zholos AV. Muscarinic effects on ion channels in smooth muscle cells. Neurophysiology 1999; 31: 212-28.

38 Janssen LJ, Sims SM. Acetylcholine activates non-selective cation and chloride conductances in canine and guinea-pig tracheal myocytes. J Physiol 1992; 453: 197-218.

39 Carl A, Lee HK, Sanders KM. Regulation of ion channels in smooth muscles by calcium. Am J Physiol 1996; 271: C9-34.

40 Lee HK, Bayguinov O, Sanders KM. Role of nonselective cation current in muscarinic responses of canine colonic muscle. Am J Physiol 1993; 265: C1463-71.

41 Inoue R, Kitamura K, Kuriyama H. Acetylcholine activates single sodium channels in smooth muscle cells. Pflugers Arch 1987; 410: 69-74.

42 Zholos AV, Bolton TB. Effects of divalent cations on muscar- inic receptor cationic current in smooth muscle from guinea-pig small intestine. J Physiol 1995; 486: 67-82.

43 Kim SJ, Koh EM, Kang TM, Kim YC, So I, Isenberg G, et al. $\mathrm{Ca}^{2+}$ influx through carbachol-activated non-selective cation channels in guinea-pig gastric myocytes. J Physiol 1998; 513: 749-60.

44 Wang Q, Akbarali HI, Hatakeyama N, Goyal RK. Caffeine- and carbachol-induced $\mathrm{Cl}^{-}$and cation currents in single opossum esophageal circular muscle cells. Am J Physiol 1996; 271: C1725-34.

45 Fleischmann BK, Wang YX, Kotlikoff MI. Muscarinic activation and calcium permeation of nonselective cation currents in airway myocytes. Am J Physiol 1997; 272: C341-9.

46 Takai Y, Awaya S, Takai A. Activation of non-selective cation conductance by carbachol in freshly isolated bovine ciliary muscle cells. Pflugers Arch 1997; 433: 705-12.

47 Kang TM, Kim YC, Sim JH, Rhee JC, Kim SJ, Uhm DY, et al. The properties of carbachol-activated nonselective cation channels at the single channel level in guinea pig gastric myocytes. Jpn J Pharmacol 2001; 85: 291-8.

48 Zholos AV, Tsvilovskyy VV, Bolton TB. Muscarinic cholinergic excitation of smooth muscle: signal transduction and single cationic channel properties. Neurophysiology 2003; 35: 283-301.

49 Zholos AV, Zholos AA, Bolton TB. G-protein-gated TRP-like cationic channel activated by muscarinic receptors: effect of potential on single-channel gating. J Gen Physiol 2004; 123 : 581-98.

50 Inoue R. Effect of external $\mathrm{Cd}^{2+}$ and other divalent cations on carbachol-activated non-selective cation channels in guinea-pig ileum. J Physiol 1991; 442: 447-63.

51 Inoue R, Kuriyama H. Dual regulation of cation-selective channels by muscarinic and $\alpha 1$-adrenergic receptors in the rabbit portal vein. J Physiol 1993; 465: 427-48.

52 Vogalis F, Sanders KM. Cholinergic stimulation activates a nonselective cation current in canine pyloric circular muscle cells. J Physiol 1990; 429: 223-36.

53 Chen S, Inoue R, Ito Y. Pharmacological characterization of muscarinic receptor-activated cation channels in guinea-pig ileum. Br J Pharmacol 1993; 109: 793-801.

54 Kim SJ, Ahn SC, So I, Kim KW. Quinidine blockade of the carbachol-activated nonselective cationic current in guinea-pig gastric myocytes. Br J Pharmacol 1995; 115: 1407-14.

55 Zholos AV, Tsytsyura YD, Philyppov IB, Shuba MF, Bolton TB. Voltage-dependent inhibition of the muscarinic cationic current in guinea-pig ileal cells by SK\&F 96365. Br J Pharmacol 2000; 129: 695-702.

56 Tsvilovskyy VV, Zholos AV, Bolton TB. Effects of polyamines on the muscarinic receptor-operated cation current in guinea-pig ileal smooth muscle myocytes. Br J Pharmacol 2004; 143: 968-75.

57 Inoue R, Isenberg G. Effect of membrane potential on acetylcholine-induced inward current in guinea-pig ileum. J Physiol 1990; 424: 57-71.

58 Benham CD, Bolton TB, Lang RJ. Acetylcholine activates an inward current in single mammalian smooth muscle cells. Nature 1985; 316: 345-7.

59 Zholos AV, Bolton TB. G-protein control of voltage dependence as well as gating of muscarinic metabotropic channels in guinea-pig ileum. J Physiol 1994; 478: 195-202.

60 Sims SM. Cholinergic activation of a non-selective cation current in canine gastric smooth muscle is associated with contraction. J Physiol 1992; 449: 377-98.

61 Kim SJ, Ahn SC, So I, Kim KW. Role of calmodulin in the 
activation of carbachol-activated cationic current in guinea-pig gastric antral myocytes. Pflugers Arch 1995; 430: 757-62.

62 Zholos AV, Bolton TB. A novel GTP-dependent mechanism of ileal muscarinic metabotropic channel desensitization. $\mathrm{Br} \mathrm{J}$ Pharmacol 1996; 119: 997-1012.

63 Bolton TB, Zholos AV. Potential synergy: voltage-driven steps in receptor-G protein coupling and beyond. Sci STKE 2003; 2003: pe52.

64 Zholos AV, Tsvilovskyy VV, Bolton TB. Muscarinic cholinergic excitation of smooth muscle: signal transduction and single cationic channel properties. Neurophysiology 2003; 35: 283-301.

65 Tsytsyura YD, Zholos AV, Shuba MF, Bolton TB. Effects of intracellular $\mathrm{Ca}^{2+}$ on muscarinic cationic current in guinea pig ileal smooth muscle cells. Neurophysiology 2000; 32: 236-7.

66 Zholos AV, Tsytsyura YD, Gordienko DV, Tsvilovskyy VV, Bolton TB. Phospholipase $\mathrm{C}$, but not $\mathrm{InsP}_{3}$ or DAG, -dependent activation of the muscarinic receptor-operated cation current in guineapig ileal smooth muscle cells. Br J Pharmacol 2004; 141: 23-36.

67 Zhu MH, Lee YM, Jin N, So I, Kim KW. The transient receptor potential protein homologue TRPC4/5 as a candidate for the nonselective cationic channel activated by muscarinic stimulation in the murine stomach. Neurophysiology 2003; 33: 302-7.

68 Lee YM, Kim BJ, Kim HJ, Yang DK, Zhu MH, Lee KP, et al. TRPC5 as a candidate for the nonselective cation channel activated by muscarinic stimulation in murine stomach. Am J Physiol 2003; 284: G604-16.

69 Lee KP, Jun JY, Chang IY, Suh SH, So I, Kim KW. TRPC4 is an essential component of the nonselective cation channel activated by muscarinic stimulation in mouse visceral smooth muscle cells. Mol Cells 2005; 20: 435-41.

70 Clapham DE, Montell C, Schultz G, Julius D. International Union of Pharmacology. XLIII. Compendium of voltage-gated ion channels: transient receptor potential channels. Pharmacol Rev 2003; 55: 591-6.

71 Zholos AV, Bolton TB, Dresvyannikov AV, Kustov MV, Tsvilovskii VV, Shuba MF. Cholinergic excitation of smooth muscles: multiple signaling pathways linking $\mathrm{M}_{2}$ and $\mathrm{M}_{3}$ muscarinic receptors to cationic channels. Neurophysiology 2004; 36: $398-406$.

72 Komori S, Unno T, Nakayama T, Ohashi H. $\mathrm{M}_{2}$ and $\mathrm{M}_{3}$ muscarinic receptors couple, respectively, with activation of nonselective cationic channels and potassium channels in intestinal smooth muscle cells. Jpn J Pharmacol 1998; 76: 213-8.

73 Zholos AV, Komori S, Ohashi H, Bolton TB. $\mathrm{Ca}^{2+}$ inhibition of inositol trisphosphate-induced $\mathrm{Ca}^{2+}$ release in single smooth muscle cells of guinea-pig small intestine. J Physiol 1994; 481: 97-109.

74 Komori S, Kawai M, Pacaud P, Ohashi H, Bolton TB. Oscillations of receptor-operated cationic current and internal calcium in single guinea-pig ileal smooth muscle cells. Pflugers Arch 1993; 424: 431-8.

75 Gordienko DV, Zholos AV, Bolton TB. Membrane ion channels as physiological targets for local $\mathrm{Ca}^{2+}$ signalling. J Microsc $=$ 1999; 196: 305-16.

76 Gordienko DV, Zholos AV. Regulation of muscarinic cationic current in myocytes from guinea-pig ileum by intracellular $\mathrm{Ca}^{2+}$ release: a central role of inositol 1,4,5-trisphosphate receptors. Cell Calcium 2004; 36: 367-86.

77 Komori S, Iwata M, Unno T, Ohashi H. Modulation of carba- chol-induced $\left[\mathrm{Ca}^{2+}\right]_{\mathrm{i}}$ oscillations by $\mathrm{Ca}^{2+}$ influx in single intestinal smooth muscle cells. Br J Pharmacol 1996; 119: 245-52.

78 Kohda M, Komori S, Unno T, Ohashi H. Carbachol-induced $\left[\mathrm{Ca}^{2+}\right]_{\mathrm{i}}$ oscillations in single smooth muscle cells of guinea-pig ileum. J Physiol 1996; 492: 315-28.

79 Tsytsyura YD, Zholos AV, Shuba MF, Bolton TB. Effects of intracellular $\mathrm{Ca}^{2+}$ on muscarinic cationic current in guinea pig ileal smooth muscle cells. Neurophysiology 2000; 32: 236-7.

80 Kim YC, Kim SJ, Sim JH, Jun JY, Kang TM, Suh SH, et al. Protein kinase $\mathrm{C}$ mediates the desensitization of $\mathrm{CCh}$-activated nonselective cationic current in guinea-pig gastric myocytes. Pflugers Arch 1998; 436: 1-8.

81 Dresvyannikov AV, Bolton TB, Zholos AV. Properties of single muscarinic receptor-gated cation channels in murine intestinal myocytes. J Physiol 2005; 568P: PC14.

82 Mironneau J, Arnaudeau S, Macrez-Lepretre N, Boittin FX. $\mathrm{Ca}^{2+}$ sparks and $\mathrm{Ca}^{2+}$ waves activate different $\mathrm{Ca}^{2+}$-dependent ion channels in single myocytes from rat portal vein. Cell Calcium 1996; 20: $153-60$.

83 Schaefer M, Plant TD, Obukhov AG, Hofmann T, Gudermann T, Schultz G. Receptor-mediated regulation of the nonselective cation channels TRPC4 and TRPC5. J Biol Chem 2000; 275: 17517-26.

84 Kanki H, Kinoshita M, Akaike A, Satoh M, Mori Y, Kaneko S. Activation of inositol 1,4,5-trisphosphate receptor is essential for the opening of mouse TRP5 channels. Mol Pharmacol 2001; 60: 989-98

85 Plant TD, Schaefer M. Receptor-operated cation channels formed by TRPC4 and TRPC5. Naunyn-Schmiedeberg's Arch Pharmacol 2005; 371: 266-76.

86 Okamoto H, Unno T, Arima D, Suzuki M, Yan HD, Matsuyama $\mathrm{H}$, et al. Phospholipase $\mathrm{C}$ involvement in activation of the muscarinic receptor-operated cationic current in guinea pig ileal smooth muscle cells. J Pharmacol Sci 2004; 95: 203-13.

87 Rhee SG. Regulation of phosphoinositide-specific phospholipase C. Ann Rev Biochem 2001; 70: 281-312.

88 Rebecchi MJ, Pentyala SN. Structure, function, and control of phosphoinositide-specific phospholipase C. Physiol Rev 2000; 80: $1291-335$.

89 Komori S, Unno T, Matsuyama H, Sakamoto T, Kitazawa T, Taneike $\mathrm{T}$, et al. Muscarinic receptor-mediated cationic current in intestinal smooth muscle of $\mathrm{M}_{2}$ or $\mathrm{M}_{3}$ receptor knockout mouse. J Physiol 2005; 568P: SA20.

90 Inoue R, Waniishi Y, Yamada K, Ito Y. A possible role of tyrosine kinases in the regulation of muscarinic receptor-activated cation channels in guinea pig ileum. Biochem Biophys Res Commun 1994; 203: 1392-7.

91 Murthy KS, Makhlouf GM. Functional characterization of phosphoinositide-specific phospholipase $C-\beta 1$ and $-\beta 3$ in intestinal smooth muscle. Am J Physiol 1995; 269: C969-78.

92 Kim YC, Kim SJ, Kang TM, Suh SH, So I, Kim KW. Effects of myosin light chain kinase inhibitors on carbachol-activated nonselective cationic current in guinea-pig gastric myocytes. Pflugers Arch 1997; 434: 346-53.

93 Sakamoto T, Unno T, Matsuyama H, Uchiyama M, Hattori M, Nishimura $\mathrm{M}$, et al. Characterization of muscarinic receptormediated cationic currents in longitudinal smooth muscle cells of mouse small intestine. J Pharmacol Sci 2006; 100: 215-26. 